\title{
Commentary
}

\section{Olfactory and taste disorders in COVID-19 patients: an update}

\author{
Mohd Abu Bashar ${ }^{1 *}$, Nazia Begam² \\ ${ }^{1}$ Department of Community Medicine, MM Institute of Medical Sciences \& Research, MM Deemed University, \\ Mullana, Haryana, India \\ ${ }^{2}$ Department of ENT, ECHS Hospital, Naraingarh, Haryana, India
}

Received: 06 May 2020

Accepted: 11 June 2020

\section{*Correspondence:}

Dr. Mohd Abu Bashar,

E-mail: imback20006@yahoo.in

Copyright: (C) the author(s), publisher and licensee Medip Academy. This is an open-access article distributed under the terms of the Creative Commons Attribution Non-Commercial License, which permits unrestricted non-commercial use, distribution, and reproduction in any medium, provided the original work is properly cited.

\section{INTRODUCTION}

Since December 2019, a pandemic of coronavirus disease 2019 (COVID-19) caused by severe acute respiratory syndrome coronavirus 2 (SARS-CoV-2) has spread globally. ${ }^{1,2}$ A spectrum of disease severity has been reported for the infection, with main symptoms of fever, fatigue, dry cough, myalgia, and dyspnoea. ${ }^{3}$

Previous strains of coronavirus have been demonstrated to invade the central nervous system through the olfactory neuroepithelium and propagate from within the olfactory bulb. ${ }^{4}$ Furthermore, nasal epithelial cells display the highest expression of the SARS-CoV-2 receptor, angiotensin-converting enzyme 2 , in the respiratory tree. ${ }^{5}$

It has been observed that SARS-CoV-2 does not appear to generate clinically significant nasal congestion or rhinorrhoea-i.e., a red, runny, stuffy, itchy nose. This observation suggests a neurotropic virus that is sitespecific for the olfactory system. Although labelled as a virus affecting respiratory system, coronaviruses are known to be neurotropic and neuroinvasive. ${ }^{6-9}$

Olfactory and taste disorders are well known to be related with a wide range of viral infections. ${ }^{10,11}$ In a mice model, SARS-CoV has demonstrated a transneural penetration through the olfactory bulb. ${ }^{12}$ Moreover, angiotensin converting enzyme 2 receptor, which is used by SARSCoV-2 to bind and penetrate into the cell, is widely expressed on the epithelial cells of the mucosa of the oral cavity. ${ }^{13}$ These findings could explain the underlying pathogenetic mechanism of taste and olfactory disorders in SARS-CoV-2 infection.

\section{STUDIES ON SMELL AND TASTE DYSFUN- CTION IN PATIENTS WITH COVID-19}

Giacomelli et al performed a cross-sectional survey of the prevalence of these alterations in the context of SARSCoV-2 infection after some patients admitted for COVID-19, at the Infectious Disease Department of L. Sacco Hospital in Milan, Italy, complained of olfactory and taste disorders (OTDs). ${ }^{14}$ Of 88 hospitalized patients, 59 were able to be interviewed (29 were nonrespondents, of whom 4 had dementia, 2 had a linguistic barrier, and 23 were on non-invasive ventilation). Of these, $20(33.9 \%)$ reported at least 1 taste or olfactory disorder and $11(18.6 \%)$ both. Twelve patients (20.3\%) presented the symptoms before the hospital admission, whereas $8(13.5 \%)$ experienced the symptoms during the hospital stay. Taste alterations were more frequently (91\%) before hospitalization, whereas after hospitalization taste and olfactory alteration appeared with equal frequency. Females reported OTDs more frequently than males $10 / 19(52.6 \%)$ vs $10 / 40$ (25\%); $\mathrm{p}=0.036$ ). Moreover, patients with at least 1 OTD were younger than those without (median, 56 years [interquartile range (IQR), 47-60] vs 66 [IQR, 52-77]; $\mathrm{p}=0.035) .^{14}$

Spinato et al evaluated prevalence, intensity, and timing of an altered sense of smell or taste in patients with mildly symptomatic SARS-CoV-2 infection. ${ }^{15}$ Any altered sense of smell or taste was reported by $64.4 \%$ (95\% CI, $57.3 \%-71.0 \%)$ out of which $34.6 \%$ also reported blocked nose. Other frequent symptoms were fatigue $(68.3 \%)$, dry or productive cough $(60.4 \%)$, and fever $(55.5 \%)$. Among all patients, the timing of an altered sense of smell or taste onset in relation to other 
symptoms occurred before other symptoms in $11.9 \%$; at same time as in 22.8\%; and after other symptoms in $26.7 \%$. An altered sense of smell or taste was reported as the only symptom by $3.0 \%$. An altered sense of smell or taste was more frequent among women $(72.4 \%, 95 \% \mathrm{CI}$ : $62.8 \%-80.7 \%)$ than among men $(55.7 \%, 95 \%$ CI: $45.2 \%$ $65.8 \% ; \mathrm{p}=0.02){ }^{15}$

Xydacis et al have observed that anosmia, with or without dysgeusia, manifests either early in the disease process or in patients with mild or no constitutional symptoms. ${ }^{16}$

\section{CONCLUSION}

Olfactory and taste disorders are fairly frequent in patients with SARS-CoV-2 infection and may precede the onset of full-blown clinical disease. Alterations in smell or taste were frequently reported by mildly symptomatic patients with SARS-CoV-2 infection and often were the first apparent symptom. Consideration should be given to testing and self-isolation of patients with new onset of altered taste or smell during the COVID-19 pandemic.

\section{REFERENCES}

1. World Health Organisation (WHO) Coronavirus disease (COVID-19) outbreak. Available at: https://experience.arcgis.com/experience/685d0ace5 21648 f8a5beeee $1 b 9125 \mathrm{~cd}$. Accessed on 25 April, 2020.

2. Cucinotta D, Vanelli M. WHO declares COVID-19 a pandemic. Acta Biomed. 2020;91:157-60.

3. Dubé M, Le Coupanec A, Wong AHM, Rini JM, Desforges M, Talbot PJ. Axonal transport enables neuron-to-neuron propagation of human coronavirus OC43. J Virol. 2018;92(17):e00404-18.

4. Sungnak W, Huang N, Bécavin C, Berg M, Network HLB. SARS-CoV-2 entry genes are most highly expressed in nasal goblet and ciliated cells within human airways. ArXiv200306122 Q-Bio, 2020.

5. Huang C, Wang Y, Li X, Ren L, Zhao J, Hu Y, et al. Clinical features of patients infected with 2019 novel coronavirus in Wuhan, China. Lancet. 2020;395:497-506.

6. Desforges M, Le Coupanec A, Brison E, MeessenPinard M, Talbot PJ. Neuroinvasive and neurotropic human respiratory coronaviruses: potential neurovirulent agents in humans. Adv Exp Med Biol. 2014;807:75-96.

7. Li Y, Bai W, Hashikawa T. The neuroinvasive potential of SARS-CoV2 may play a role in the respiratory failure of COVID-19 patients. J Med Virol. 2020.

8. Suzuki M, Saito K, Min WP, Vladau C, Toida K, Itoh $\mathrm{H}$, et al. Identification of viruses in patients with postviral olfactory dysfunction. Laryngoscope. 2007;117:272-7.

9. Mao L, Wang M, Chen S, He Q, Chang J, Hong C, et al. Neurological manifestations of hospitalized patients with COVID-19 in Wuhan, China: a retrospective case series study. SSRN 2020.

10. Hummel T, Landis BN, Hüttenbrink KB. Smell and taste disorders. GMS Curr Top Otorhinolaryngol Head Neck Surg. 2011;10:04.

11. van Riel D, Verdijk R, Kuiken T. The olfactory nerve: a shortcut for influenza and other viral diseases into the central nervous system. J Pathol 2015;235:277-87.

12. Netland J, Meyerholz DK, Moore S, Cassell M, Perlman S. Severe acute respiratory syndrome coronavirus infection causes neuronal death in the absence of encephalitis in mice transgenic for human ACE2. J Virol. 2008;82:7264-75.

13. Xu H, Zhong L, Deng J, Peng J, Dan H, Zeng X, et al. High expression of ACE2 receptor of 2019$\mathrm{nCoV}$ on the epithelial cells of oral mucosa. Int $\mathbf{J}$ Oral Sci. 2020;12:8.

14. Giacomelli A, Pezzati L, Conti F. Self-reported olfactory and taste disorders in SARS-CoV-2 patients: a cross-sectional study. Clin Infect Dis. 2020.

15. Spinato G, Fabbris C, Polesel J, Cazzador D, Borsetto D, Hopkins C, et al. Alterations in Smell or Taste in Mildly Symptomatic Outpatients With SARS-CoV-2 Infection. JAMA. 2020;323(20):2089-90.

16. Xydacis MS, Dehgani-Mobaraki P, Holbrook HE, Geisthof UW, Bauer C, et al. Smell and taste dysfunction in patients with COVID-19. The Lancet Infectious Dis. 2020.

Cite this article as: Bashar MA, Begam N. Olfactory and taste disorders in COVID-19 patients: an update. Int J Sci Rep 2020;6(9):379-80. 